\title{
WEATHER AND TRAFFIC MONITORING SYSTEM IoT-Based TOWARDS JAMBI SMART CITY
}

\author{
Imti Tsalil Amri ${ }^{1}$, Santoso ${ }^{2}$, Teuku Djauhari ${ }^{3}$, Brestina Gultom ${ }^{4}$ \\ 1,2,4 Fakultas Teknik dan Ilmu Komputer, Universitas Adiwangsa Jambi, Jambi \\ ${ }^{3}$ Teknik Informatika, STMIK Nurdin Hamzah, Jambi
}

\section{Article Info \\ Article history: \\ Received 21 May 2021 \\ Revised 09 June 2021 \\ Accepted 09 June 2021}

\section{Keywords:}

Smart City

Lalu Lintas

Cuaca

Internet of Things

Arduino

\begin{abstract}
PT)
With the large number of vehicles on the road today, we often get stuck in a traffic jam on our way to a place. And the temperature or the weather that often changes sometimes also causes us to get stuck in a weather. Thus both these problems was made a journal WEATHER AND TRAFFIC MONITORING SYSTEM IoT-BASED TOWARDS JAMBI SMART CITY. This research uses descriptive research method. This method uses action techniques that focus on implementing actions with the aim of improving quality or solving problems in a group of objects and observing the success rate or impact of their actions.
\end{abstract}

This is an open access article under the CC BY-SA license.

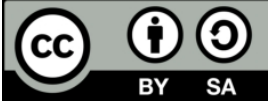

\section{Corresponding Author:}

Imti Tsalil Amri, S.Kom., M.Kom Fakultas Teknik dan Ilmu Komputer Universitas Adiwangsa Jambi Jambi, Indonesia Email: imti.tsalil@gmail.com (C) The Author(s) 2021

\section{Introduction}

Supporting Jambi city government's program towards smart city and building the vision and the concept, it is necessary to implement the development program of Jambi City. At least the appreciation came back from the academic world. From observation the development of information technology nowadays, the era of industrial revolution 4.0. It is the digital era uses internet as connectivity or internet of things. It is necessary to increase and effectively use information technology as the application of the internet of things. Problems occured in modern society are the need for updated and real time information regarding traffic congestion information in the city of Jambi, especially during working hours in the morning and evening where road users are often stuck in long traffic jams during peak hours. Weather information also needs to be supported to know the weather conditions, whether it's rain or wind conditions as driving safety guide. So researchers need 
to conduct the research and implement to answer these problems. The method used is descriptive method with action research techniques. This research will also be published in an accredited National Journal.

\section{Research Method}

The concept of this research is worthy in applying Jambi Smart City. Research methods are used to obtain data for certain purposes and uses. The research activity was carried out based on scientific characteristics, it likes rational, empirical and systematic. Rational means that the research was conducted by logic or common sense. Empirical means that the methods or techniques used during the research can be observed by human senses. This research used descriptive method because the problem solving procedure investigated by describing the state of subject or object, it can be people, institutions, communities and others based on visible facts. This descriptive method has the following characteristics:

1. Focusing on the research problems or actual problems

2. Describing the facts about the problem being investigated as it is, accompanied by balanced rational interpretation

3. Providing the research phenomena, explaining relationships, testing hypotheses, making predictions, and obtaining the meaning and implications from a problem.

\section{Result and Discussion}

In completing this research, it starts from finding the literature and references in making Weather and Traffic Monitoring System IoT-Based Towards Jambi Smart City. This research completed and able to produce the expected results. The display obtained are temperature display and the state of the road, such as quiet, smooth, and congest or jammed. The tools used for this research are the following :

1. ES8266 wifi module

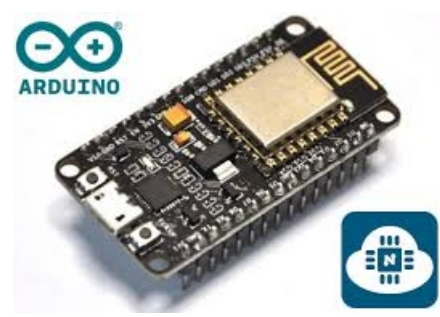

2. HC-SR04 censor

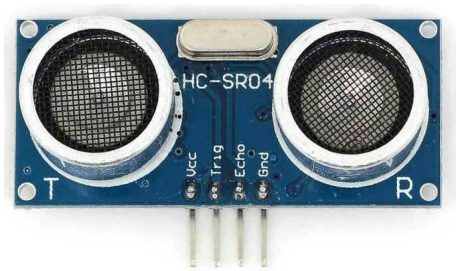




\section{DHT11 censor}

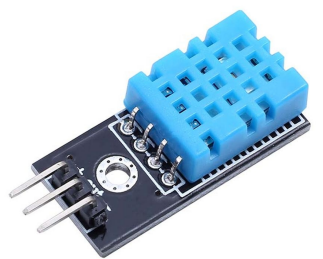

From these tools, a circuit is made as shown in the figure below:

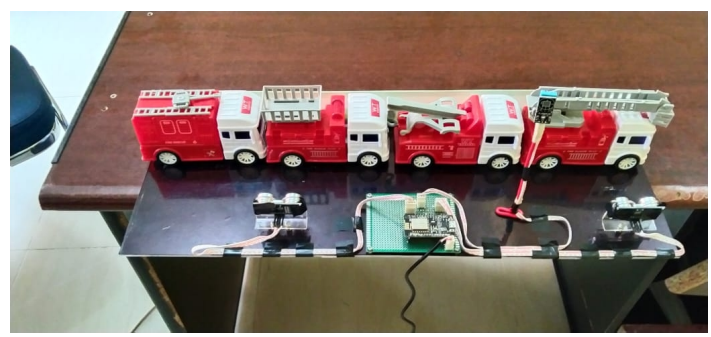

Figure 1. Tools Display

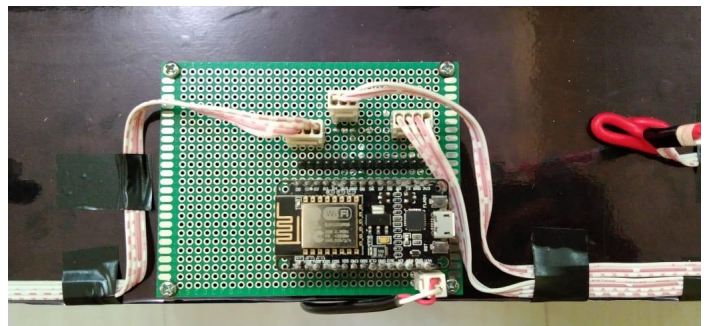

Figure 2. Circuits Display

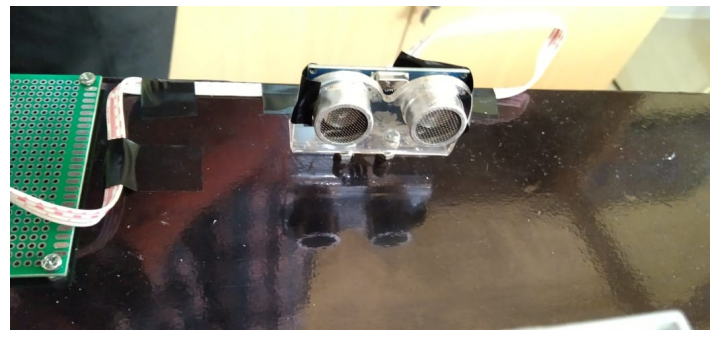

Figure 3. HC-SR04 Censor Position

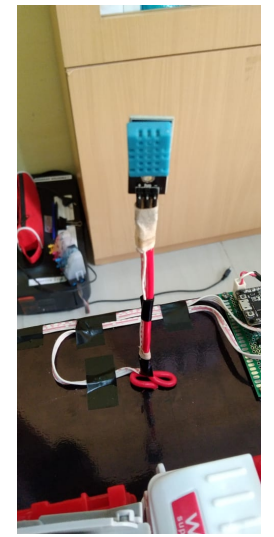


Figure 4. DHT11 Censor Position

The scheme of monitoring tool will analyze vehicles that pass the censor. Incoming and outgoing vehicles will be compared the results. If there are no vehicles within the range of 2 censors of HC-SR04, so the road status is quiet, if $>=1$ the status is smooth, and if $>=2$ the status is congest.

The scheme of temperature monitoring, the DHT11 censor will read the temperature at that time. The results of traffic conditions and temperatures will be sent by the ESP8266 module to the website and the results will appear on that website.

\section{Conclusion}

Based on the description above, it can be concluded that the society can find out the conditions of road congestion and weather at certain locations by opening website to get answers from that conditions.

\section{Acknowledgement}

In finishing this research, it fully thanks to the team, LPPM of Adiwangsa University Jambi, and also Directorate of Research and Community Service.

\section{References}

[1] Dennis, Alan; Wixom, Haley Barbara: \& Tegarden, David. 2010. Systems Analysis and Design with UML Version 2.0 : An Object-Oriented Approach. Second Edition. United States of America : John Wiley \& Sons, Inc

[2] Hutahaean, J. (2015). Konsep sistem informasi. Deepublish

[3] Hidayatulloh, S. and Teknik, F. (2016) 'Internet Of Things Bandung Smart City', 3(September), pp. 164175

[4] Mandarani, P. (2014) 'PERANCANGAN DAN IMPLEMENTASI USER INTERFACE BERBASIS WEB UNTUK MONITORING SUHU , KELEMBABAN DAN ASAP PADA RUANGAN BERBEDA DENGAN MEMANFAATKAN', 2(2), pp. 37-42

[5] Mandarani, P. (2014). Perancangan Dan Implementasi User Interface Berbasis Web Untuk Monitoring Suhu, Kelembaban Dan Asap Pada Ruangan Berbeda Dengan Memanfaatkan, 2(2), 37-42

[6] Mandarani, P. (2014). Perancangan Dan Implementasi User Interface Berbasis Web Untuk Monitoring Suhu, Kelembaban Dan Asap Pada Ruangan Berbeda Dengan Memanfaatkan, 2(2), pp. 37-42

[7] Pemkotjambi, 2019. Menuju Kota Jambi https://jambikota.go.id/new/geografis/https://metrojambi.com/read/2017/10/18/25973/menuju-kota-jambi-smartcity-berbasis-teknologi-

[8] Santoso, S. and Amri, I.T., 2018. MEMBANGUN APLIKASI BEL OTOMATIS BERBASIS MIKROKONTROLER DI SMA UNGGUL SAKTI JAMBI. JOURNAL V-TECH (VISION TECHNOLOGY), 1(2), pp.1-13

[9] Syafrizal, Melwin., 2005. Pengantar Jaringan Komputer, Penerbit Andi : Yogyakarta

[10] Tranggono, E. P. et al. (no date). Rancang Bangun Sistem Informasi Kontrol Kondisi Lalu Lintas Dengan Kamera Pemantau CCTV Berbasis GIS. 